\title{
College Students' Prepositions Avoidance Phenomenon in English Writing
}

\author{
Chunli LIU \\ City College, Wuhan University of Science and Technology, Wuhan, 430083, China \\ E-mail: 25467278@qq.com
}

Key words: Avoidance; Prepositions; English writing; College students

\begin{abstract}
Through English writing and questionnaires, this research is intended to study the prepositions avoidance phenomenon in English writing of different-level English learners and explore its reasons. We find that college English learners at low-to-medium level obviously incline to avoid prepositions while those at medium-to-high level have no tendency to avoid prepositions. Thus, we can conclude that the low-level English is the major reason of avoiding prepositions while interlingual differences, complexity of target language, psychological and emotional factors can also be its reasons.
\end{abstract}

\section{Introduction}

With respect to avoidance phenomenon, many domestic scholars, including Shu Dingfang \& Zhuang Zhixiang(1996), Li Yuling \& Wang Hong(2004), Qiu Jixin(2004), Ruan Zhoulin(2000), Wang Jinba(2010)and so on, have conducted studies on it mainly from the perspectives of description, classification and combination with classroom teaching practice. Besides, some other scholars have also done empirical studies on the avoidance phenomenon of specific language items in English writing. For instance, Chen Yuehong (1999) has studied the avoidance phenomenon of relative clause in English writing, Zhang Bin(2007) and Guo Wei(2013) have studied the avoidance of phrasal verbs of English learners at different levels, Wang Raiying (2014) found that non-English majors inclined to avoid adverbial participial clause and Chen Changyong (2014) has analyzed the avoidance of two types of English compound words by investigating 30 different-level English majors. [1] [2] However, though domestic scholars have conducted a lot of studies from various aspects, there are still some limitations and problems when studying the avoidance of certain language items. [3]For example, some studies didn’t establish clear standard of avoidance, merely focused on domestic English learners, didn't have comparative reference of native speakers when identifying learners' low output of certain linguistic structure and didn't clearly define the avoidance behavior.

\section{Research Design}

\section{A. Research Question}

Through an empirical study, this paper is intended to answer the following questions:

(1) Whether Chinese English learners and native speakers have significant difference in their written use of prepositions?

(2)If there is obvious difference, could it indicate that Chinese English learners always avoid prepositions in writing? 


\section{B. Subjects}

The subjects of this research are 13 English-speaking teachers in colleges, 30 junior English majors of a class and 30 freshman non-English majors of another class from a college in Hubei. They are divided into three groups: the group of native speakers, the group of English learners at medium-to-high level and the group of learners at low-to-medium level.

\section{Research Tools}

The research tools here are English picture compositions and questionnaire. As for the English picture compositions, the subjects are firstly required to observe and understand a comic strip which totally consists of 8 pictures and tells a story about animals. [4]Then, they are considered to write 2 to 4 sentences for each picture for comparative analysis and finally complete English writing about 300 words. In terms of the questionnaire, it mainly includes two parts. The first part is the personal information of each subject. [5]The second part proposes 5 questions which are in regards to the research questions above and aimed to find the reasons of avoiding prepositions.

\section{Data Collection}

The learners at low-to-medium level and medium-to-high level are required to complete their English writing in 50 minutes and then fill in the questionnaire. With their writing and questionnaire are all collected in class, the author will analyze them and obtain the data.

\section{Results and Discussion}

Before the analysis of the data, we prefer to reconfirm the research questions: (1)Whether Chinese English learners and native speakers have obvious difference in their written use of prepositions? (2)If there is obvious difference, could it indicate that Chinese English learners always avoid prepositions in writing?

According to the data analysis approach above, we firstly compare the prepositions frequency of English learners and Native speakers.

The data is shown in Table 1.

Table 1Comparison of prepositions frequency between English learners and nativespeakers

\begin{tabular}{ccccc}
\hline Group & Number & Mean & Sd. & SE Mean \\
\hline English learners & 60 & 32.9033 & 10.64418 & 1.37416 \\
Native speakers & 13 & 36.0308 & 9.91685 & 2.75044 \\
\hline
\end{tabular}

Table 1 shows that the mean frequency of prepositions of English learners is 32.9033 while that of native speakers is 36.0308. The difference between these two numbers indicates that English learners incline to use fewer prepositions than native speakers in English picture compositions. [6]To further examine whether this two groups have significant difference in the use of prepositions, the author applies the independent sample T test.

The results are shown in Table 2. 
Table 2 Results of independent sample T test

\begin{tabular}{|c|c|c|c|c|c|c|c|c|c|}
\hline & \multicolumn{2}{|c|}{$\begin{array}{l}\text { Levene test of } \\
\text { variance } \\
\text { equation }\end{array}$} & \multicolumn{7}{|c|}{$\mathrm{T}$ test of mean equation } \\
\hline & \multirow[b]{2}{*}{$\mathrm{F}$} & \multirow[b]{2}{*}{ Sig. } & \multirow[b]{2}{*}{$\mathrm{t}$} & \multirow[b]{2}{*}{$\mathrm{df}$} & \multirow[b]{2}{*}{$\begin{array}{l}\text { Sig.(2-t } \\
\text { ailed) }\end{array}$} & \multirow[b]{2}{*}{$\begin{array}{c}\text { Mean } \\
\text { differenc } \\
\text { e }\end{array}$} & \multirow[b]{2}{*}{ SE } & \multicolumn{2}{|c|}{$\begin{array}{c}\text { 95\% confidence } \\
\text { intervals(CIs) }\end{array}$} \\
\hline & & & & & & & & $\begin{array}{l}\text { Lower } \\
\text { limit }\end{array}$ & $\begin{array}{l}\text { Upper } \\
\text { limit }\end{array}$ \\
\hline $\begin{array}{l}\text { Equalvariance } \\
\text { assumed } \\
\text { Inequalvariance } \\
\text { assumed }\end{array}$ & .125 & .725 & $\begin{array}{l}-.971 \\
-1.017\end{array}$ & 18.504 & $\begin{array}{l}.335 \\
.322\end{array}$ & $\begin{array}{l}-3.12744 \\
-3.12744\end{array}$ & $\begin{array}{c}3.219 \\
79 \\
3.074 \\
61\end{array}$ & $\begin{array}{l}-9.54751 \\
-9.57437\end{array}$ & $\begin{array}{c}3.2926 \\
4 \\
3.3195 \\
0\end{array}$ \\
\hline
\end{tabular}

Table 2 tells us that the $\mathrm{P}$ value of Levene test is 0.725 , higher than 0.05 . Thus, the data in the case of "equal variance assumed" is effective. The P value of 2-tailed $\mathrm{T}$ test is 0.335 , higher than 0.05. That means the difference between two groups is not significant. In other words, English learners and native speakers have no significant difference in the use of prepositions in English writing. Hence, we can conclude that Chinese English learners don't avoid prepositions in English writing.

Since the comic strip consists of 8 pictures, most students prefer to use special prepositions like over, in and on which are all free prepositions. Thus, the proportion of free prepositions is accordingly high which is in accordance with the data in Table 3.

Table 3Total number and proportion of two kinds of prepositions

\begin{tabular}{|c|c|c|c|c|c|}
\hline Group & $\begin{array}{l}\text { Total number } \\
\text { of prepositions }\end{array}$ & $\begin{array}{l}\text { Total number } \\
\text { of free } \\
\text { prepositions }\end{array}$ & $\begin{array}{l}\text { Proportion } \\
\text { of free } \\
\text { prepositions }\end{array}$ & $\begin{array}{l}\text { Total number } \\
\text { of adhesive } \\
\text { prepositions }\end{array}$ & $\begin{array}{l}\text { Proportion } \\
\text { of adhesive } \\
\text { prepositions }\end{array}$ \\
\hline $\begin{array}{l}\text { Group of } \\
\text { low-to-medium } \\
\text { students ( } 30 \\
\text { pieces of writing })\end{array}$ & 559 & 474 & $85 \%$ & 85 & $15 \%$ \\
\hline $\begin{array}{l}\text { Group of } \\
\text { medium-to-high } \\
\text { students ( } 30 \\
\text { pieces of writing) }\end{array}$ & 714 & 587 & $82 \%$ & 127 & $18 \%$ \\
\hline $\begin{array}{l}\text { Group of native } \\
\text { speakers ( } 13 \\
\text { pieces of writing ) }\end{array}$ & 331 & 265 & $80 \%$ & 66 & $20 \%$ \\
\hline
\end{tabular}

It may be the large proportion of free prepositions that leads to no significant difference in the use of prepositions of Chinese English learners and native speakers. [7] Then here comes the question that whether Chinese English learners only avoid adhesive prepositions in English writing. To answer this question, the author makes a comparison of each group's frequency of adhesive prepositions and accordingly applies independent sample $\mathrm{T}$ test. The results are shown in Table 4 
and Table 5. From these two tables, we can find that English learners use fewer adhesive prepositions in English writing than native speakers. [8] But the difference between them is not significant enough. Therefore, we can conclude that the type of prepositions doesn't have obvious effect on the prepositions avoidance behavior of Chinese English learners. [9]

Table 4Comparison of the frequency of adhesive prepositions

\begin{tabular}{lcccc}
\hline Group & Number & Mean & $\begin{array}{c}\text { Standard } \\
\text { deviation }\end{array}$ & SE Mean \\
\hline Group of English learners & 60 & 5.4175 & 3.18711 & .41145 \\
Group of native speakers & 13 & 7.4462 & 4.36666 & 1.21109 \\
\hline
\end{tabular}

Table 5Independent $\mathrm{T}$ test of adhesive prepositions

\begin{tabular}{|c|c|c|c|c|c|c|c|c|c|}
\hline & \multicolumn{2}{|c|}{$\begin{array}{c}\text { Levene test } \\
\text { of variance } \\
\text { equation }\end{array}$} & \multicolumn{7}{|c|}{$\mathrm{T}$ test of mean equation } \\
\hline & \multirow[b]{2}{*}{$\mathrm{F}$} & \multirow[b]{2}{*}{ Sig. } & \multirow[b]{2}{*}{$\mathrm{t}$} & \multirow[b]{2}{*}{ df } & \multirow[b]{2}{*}{$\mid \begin{array}{c}\text { Sig.( } \\
\text { 2-tail } \\
\text { ed) }\end{array}$} & \multirow[b]{2}{*}{$\begin{array}{c}\text { Mean } \\
\text { difference }\end{array}$} & \multirow[b]{2}{*}{ SE } & \multicolumn{2}{|c|}{$\begin{array}{c}95 \% \\
\text { confidence } \\
\text { intervals(CIs) }\end{array}$} \\
\hline & & & & & & & & $\begin{array}{l}\text { Lower } \\
\text { limit }\end{array}$ & $\begin{array}{l}\text { Upper } \\
\text { limit }\end{array}$ \\
\hline $\begin{array}{l}\text { Equalvariance } \\
\text { assumed }\end{array}$ & 1.419 & .238 & -1.942 & 71 & .056 & -2.02865 & $\begin{array}{c}1.044 \\
79\end{array}$ & $\begin{array}{c}-4.1119 \\
1\end{array}$ & $\begin{array}{c}.0546 \\
1\end{array}$ \\
\hline $\begin{array}{l}\text { Inequalvariance } \\
\text { assumed }\end{array}$ & & & -1.586 & $\begin{array}{c}14.89 \\
0\end{array}$ & .134 & -2.02865 & $\begin{array}{c}1.279 \\
08\end{array}$ & $\begin{array}{c}-4.7567 \\
0\end{array}$ & $\begin{array}{c}.6994 \\
0\end{array}$ \\
\hline
\end{tabular}

Above all, we can conclude that Chinese English learners and native speakers have no significant difference in their use of prepositions in English writing as well as have no tendency to avoid prepositions. [10]However, since the English level of different English learners is different, it is necessary to respectively analyze the preposition avoidance behavior of the low-to-medium students and medium-to-high students so as to find out the difference between these two groups, namely the answer of the second research question.

\section{Conclusions}

This research finds that the low-to-medium English learners have obvious tendency to avoid prepositions while the medium-to-high learners have no tendency to do so. Among all the reasons that may lead to students' avoidance of prepositions, low English level is the major reason and the interlingual difference, the complexity of target language, mental factors and emotional factors also cannot be ignored. Thus, in the process of teaching, teachers are considered to increase language input and output, improve students' English skills, instruct students to correctly understand the interlingual difference and culture of target language create a relaxed learning environment and finally help students overcome mental hurdles and emotional hurdles. 


\section{References}

[1] Richards JC.Error Analysis: Perspectives on Second Language Acquisition. Error Analysis: Perspectives on Second Language Acquisition . 1974

[2] Odlin T.Language Transfer: Cross-linguistic Influence in Language Learning. . 1989

[3] Evan Kidd,Edith L. Bavin. English-Speaking Children's Comprehension of Relative Clauses: Evidence for General-Cognitive and Language-Specific Constraints on Development[J]. Journal of Psycholinguistic Research . 2002 (6)

[4] Dagut, M,Laufer, B.Avoidance of phrasal verbs - a case for evidence from an empirical study of SL relativisation. Studies in Second Language Acquisition . 1985

[5] Sharwood Smith M,Kellerman E.Crosslinguistic influence in second language acquisition: An introduction. Crosslinguistic influence in second language acquisition . 1986

[6] Richards Jack C,Rodgers Theodore S.Approaches and Methods in Language Teaching. . 2000

[7] Lay,N.Composing processes of adult ESL learners: a case study. Tesol Quarterly . 1982

[8] Justina Ong,Lawrence Jun Zhang. Effects of task complexity on the fluency and lexical complexity in EFL students' argumentative writing[J]. Journal of Second Language Writing. 2010 (4)

[9] Shelley Staples,Jesse Egbert,Douglas Biber,Alyson McClair. Formulaic sequences and EAP writing development: Lexical bundles in the TOEFL iBT writing section[J]. Journal of English for Academic Purposes . 2013 (3)

[10] FlorenceMyles,JanetHooper,RosamondMitchell. Rote or Rule? Exploring the Role of Formulaic Language in Classroom ForeignLanguage Learning[J]. Language Learning . 2008 (3) 